Aksaray University
Journal of Science and Engineering
e-ISSN: 2587-1277
http://dergipark.gov.tr/asujse
http://asujse.aksaray.edu.tr

Research Article

\title{
Some Microbiological Properties in Soil Samples Taken from Maize Grown Fields in Sanliurfa
}

\author{
Cigdem Kucuk*, Cenap Cevheri \\ Harran University, Science Faculty, Department of Biology, 63300 Sanliurfa, Turkey
}

\begin{abstract}
The aim of this study was to investigate some microbiological properties in soil samples taken from maize grown fields in Sanliurfa. Also, some physic-chemical properties of these soil samples were observed. The soil samples were taken from $0-20 \mathrm{~cm}$ depth of maize grown soils. The microbial biomass carbon content of soils was determined as 98.2-198.5 mg C/g dry soil. The enzyme activities studied of soil samples were urease, catalase, dehydrogenase, alkaline phosphatase, $\beta$-glucosidase. Enzyme activities of samples were differently. Positive and negative correlation were found between soil properties observed.
\end{abstract}

\section{Keywords}

Soil enzyme activity, Maize field, Sanliurfa

*Corresponding Author: Cigdem Kucuk, ckucuk@harran.edu.tr 


Aksaray University
Journal of Science and Engineering
e-ISSN: 2587-1277
http://dergipark.gov.tr/asujse
http://asujse.aksaray.edu.tr

Research Article

\title{
Şanlıurfa'da Mısır Tarımı Yapılan Tarlalardan Alınan Toprak Örneklerinde Bazı Mikrobiyal Özellikler
}

\author{
Çiğdem Küçük* , Cenap Cevheri \\ Harran Üniversitesi, Fen Edebiyat Fakültesi, Biyoloji Bölümü, Şanlıurfa, 63300, Türkiye
}

\section{Özet}

Bu çalışmanın amacı, Şanlıurfa'da mısır tarımı yapılan tarlalardan alınan toprak örneklerinde bazı mikrobiyal özelliklerin belirlenmesidir. Ayrıca bu toprakların bazı fiziko-kimyasal özellikleri incelenmiştir. Toprak örnekleri 0-20 cm derinliğinden alınmıştır. Toprakların mikrobiyal biyomas karbon içerikleri 98.2-198.5 mg C/g kuru toprak arasında değişiklik göstermiştir. Toprak örneklerinde üreaz, katalaz, dehidrogenaz, alkalin fosfataz, $\beta$-glukosidaz enzim aktiviteleri çalışılmıştır. İncelenen örneklerde enzim aktiviteleri farklılık göstermiştir. İncelenen toprak özellikleri arasında pozitif ve negatif korelasyon belirlenmiştir.

\section{Anahtar Kelimeler}

Toprak enzim aktivitesi, Mısır tarlası, Şanlıurfa

\footnotetext{
*Sorumlu Yazar: Çiğdem Küçük, ckucuk@harran.edu.tr
} 


\section{GÍRİş}

Dünya'da buğday ve çeltikten sonra en fazla tarımı yapılan mısır bir tahıl bitkisidir. Ülkemizde ise mısır, tahıllar içerisinde buğday ve arpadan sonra üçüncü sırada yer almaktadır. Türkiye'de hemen hemen her bölgede yetiştirilmekte olan mısırın ülkemize girişinin kuzey Afrika üzerinden olduğu tahmin edilmektedir [1]. Ülkemizde 2016 yılında yaklaşık 6.820 .000 da alanda ekimi yapılan mısır üretiminin 6.300.000 ton olduğu açıklanmıştır [2]. Dünya'da ve ülkemizde mısır tarımı oldukça önem kazanmakta olup, özellikle Güneydoğu Anadolu Bölgesi'nde ikinci ürün olarak yetiştirilmekte ve ekim alanı bakımından ikinci sırada bulunmaktadir [3].

Mısır bakımı kolay olmasından dolayı, Güneydoğu Anadolu Bölgesi’ndeki çiftçiler tarafından tercih edilmektedir. Şanlıurfa ve Mardin, Güneydoğu Anadolu Bölgesi’nde en çok mısır tarımı yapılan illerdir. Şanlıurfa' da mısır tarımı Güneydoğu Anadolu Projesi'nin hayata geçirilmesiyle artmıştır [3]. Çukurova, Amik Ovası ve Güneydoğu Anadolu Bölgesi'nde yetiştirilen mısırın pamuk, buğday ve yağlı tohumlarla münavebeli olarak ekildiği bildirilmiştir [3].

Topraklar birçok bitki, hayvan ve mikroorganizmaları barındırmaktadır. Topraklardaki organizmaların topraktaki organik artıkları ayrıştırarak organik madde ve strüktürel yapının oluşumunda özellikle rol oynadığı bilinmektedir [4, 5]. Bu olayın gerçekleşmesinde mikroorganizmalar tarafından sentezlenen enzimlerin önemli rol oynadığı bildirilmiştir [6, 7]. Topraklarda ekstrasellüler enzimlerin topraklarda bulunan organik maddenin degradasyonu ile ilişkili olduğu; katalaz, dehidrogenaz, asit ve alkalin fosfataz, arilsülfataz, glukosidaz enzim aktivitelerinin toprak kalitesinin belirlenmesinde yaygın olarak kullanılabileceği yapılan çeşitli çalışmalarda rapor edilmiştir [6, 8-10].

Topraklarda bulunan mikroorganizmalar, toprağın agregat oluşumunda, besin içeriği ve organik madde parçalanmasında önemli rol oynayarak toprak kalitesinin artırılması ve düzenlenmesini sağlarlar [11]. Dolayısıyla topraktaki mikrobiyal özellikler; çevresel stres ve tarım tekniklerine karşı toprak kalitesinin değişimininde indikatör olarak tanımlanmıştır [12]. Toprak enzimlerinin kaynakları; bitki kökleri, bitki ve hayvansal kalıntılar veya mikroorganizmalar tarafından oluşturulduğu, canlı mikroorganizmalar tarafından dışarıya salınan enzimlerin, toprakta bulunan polimer bileşikleri kısa sürede parçalayarak besin iyonlarına dönüştürdükleri bildirilmiştir. Enzimlerin toprak organik maddesinin parçalanmasında önemli rol oynadığ 1 açıklanmıştır [11]. Bu nedenle toprakların enzim aktiviteleri; toprakların biyolojik aktivitesi ve verimliliğinin belirlenmesinde oldukça önemlidir [10, 12]. 
Önemli bir tarım bölgesi olan Şanlıurfa'da mısır tarımı yapılan topraklarda şimdiye kadar toprak enzimleri ile ilgili herhangi bir çalışmaya rastlanılmamıştır. Bu nedenle, mısır tarımı yapılan toprakların mikrobiyal biyomas karbon, dehidrogenaz, katalaz, $\beta$-glukosidaz, alkalin fosfataz ve üreaz enzim aktiviteleri ile bazı toprak özellikleri arasındaki ilişkinin belirlenmesi amacıyla bu çalışma yapılmıştır.

\section{MALZEME VE YÖNTEM}

\subsection{Toprak örnekleri ve analizleri}

Mısır tarımı yapılan tarlalardan, toprak örnekleri 0-20 cm toprak derinliğinden alınmıştır. Analizler için her alandan 10'ar adet toprak örneği alınmıştır. Toprak örneklerinin alındığ yerler Tablo 1'de verilmiştir. Toprak örneklerinin tekstürleri Bouyoucus hidrometre yöntemi ile, toprak örneklerinin pH's1 pH metre ( $\mathrm{pH}$ 720-WTW Inolab) ile, toprak örneklerinin kireç içerikleri kalsimetre (Scheibler tipi) ile volumetrik olarak, organik madde içeriği ise WalkeyBlack yaş yakma yöntemine göre belirlenmiştir [13].

\subsection{Dehidrogenaz aktivite}

Toprak örneği üzerine glukoz (\%0.5) ve \%3' lük 2,3,5- trifeniltetrazolium klorid eklenerek 25 ${ }^{\circ} C^{\prime}$ de 24 saat inkübe edilmiştir. Süre sonunda örnekler metanol ile ekstre edilmiş, oluşan kırmızı rengin intensitesi, trifenilformazon kullanılarak hazırlanan standart kullanılarak $485 \mathrm{~nm}$ dalga boyunda spektrofotometrik ölçümlerle belirlenmiş ve $\mu \mathrm{g}$ TPF/g kuru toprak cinsinden ifade edilmiştir [15].

\subsection{Mikrobiyal biyomas-C}

Toprak örneklerinin üzerine glukoz (200 mg) ilave edilmiş $25^{\circ} \mathrm{C}$ 'de 4 saat inkübe edilmiştir. İnkübasyon süresi sonunda üretilen $\mathrm{CO}_{2}$ miktarından mikrobiyal biyomas karbon içerikleri $40.04 \mathrm{mg} \mathrm{CO} 2 / \mathrm{g}+0.37$ eşitliği kullanılarak hesaplanmıştır [14].

\subsection{Katalaz aktivite}

Toprak örneği ( $5 \mathrm{~g}$ ) üzerine $10 \mathrm{ml}$ fosfat tampon çözeltisi ilave edilerek 10 dakika bekletilmiştir. Küçük cam tüplere $3 \mathrm{ml} \% 30$ 'luk hidrojen peroksit $\left(\mathrm{H}_{2} \mathrm{O}_{2}\right)$ konularak toprakların üzerine dökülmeyecek şekilde kavanozlara yerleştirilmiştir. Kavanozların ağızları lastik tıpa ile kapatılmış ve Scheibler kalsimetresine bağlanmıştır. Kavanoz eğilerek hidrojen peroksitin toprağa dökülmesi sağlandıktan sonra 3 dakika çalkalanarak oksijen çıkışı ml olarak belirlenmiştir [8].

\section{5. $\beta$-glukosidaz aktivite}


Toprak örneği üzerine $250 \mu \mathrm{l}$ toluen, $4 \mathrm{ml}$ tris-aminometan (pH 12), $100 \mathrm{ml}$ 0.05M p-nitrofenil $\beta$-D- glukopiranosid eklenmiş ve $37{ }^{\circ} \mathrm{C}$ 'de 1 saat inkübe edilmiştir. Süre sonunda, açığa çıkan p-nitrofenol, standart olarak PNP- $\beta$-glukopiranosid (10-100 mg) ile hazırlanan standart grafik kullanılarak $410 \mathrm{~nm}$ dalga boyunda spektrofotometrede ölçülmüş ve sonuç mg p-nitrofenol/100 g toprak cinsinden verilmiştir [16].

\section{6.Üreaz aktivite}

Toprak örneği üzerine $250 \mu \mathrm{l}$ toluen, $750 \mathrm{ml}$ sitrat tamponu ve $1 \mathrm{ml}$ üre çözeltisi (\%10'luk) eklenerek $37^{\circ} \mathrm{C}$ 'de 3 saat inkübe edilmiştir. İnkübasyon sonunda içerikte açı̆̆a çıkan amonyum miktarı $578 \mathrm{~nm}$ dalga boyunda spektrofotometre de standart grafik kullanılarak hesaplanmış, sonuç mg N/100 g toprak cinsinden verilmiştir [17].

\subsection{Alkalin fosfataz aktivite}

Toprak örneği üzerine $250 \mu \mathrm{l}$ toluen, $4 \mathrm{ml}$ fosfat tamponu (pH 8), $1 \mathrm{ml} 0.05 \mathrm{M}$ p-nitrofenilfosfat eklenerek $37^{\circ} \mathrm{C}$ de 1 saat süre ile inkübe edilmiştir. Süre sonunda açığa p-nitrofenol, PNPP'den hazırlanan (10-100 mg) standart kullanılarak 410 nm'de spektrofotometrik ölçümlerle belirlenmiş, sonuç $\mu \mathrm{g} \mathrm{pNP/g}$ kuru toprak cinsinden ifade edilmiştir [18].

\section{8.İstatistik Analiz}

İncelenen toprak özellikleri (mikrobiyal biyomas karbon, dehidrogenaz, katalaz, $\beta$-glukosidaz, üreaz, alkalin fosfataz, kum, kil ve silt içerikleri, $\mathrm{pH}$, organik madde, kireç içeriği) arası korelasyon için; her alandan alınan 10'ar adet toprak örneklerinin sonuçlarına göre JMP istatistik paket programı kullanılarak belirlenmiştir.

\section{BULGULAR VE TARTIŞMA}

Toprak örneklerine ait bazı fiziksel ve kimyasal özellikler Tablo 1'de verilmiştir. Tablo 1'de görüldüğü gibi, toprak örnekleri killi bünyeye sahip olup, organik madde içerikleri \% 0.73-2.1 arasında değişiklik göstermektedir. Örneklerin pH değerleri 7.82-8.71 arasında değişmekte olup, alkalidir. Organik maddenin düşük olması, tarımsal faaliyetler için toprağın karıştırılması, aşırı sulamadan dolayı su ile yıkanmasından kaynaklanmaktadır. Toprakların elektriksel iletkenliği 0.51-1.71 dS/m arasında belirlenmiştir. Elektriksel iletkenliği $4 \mathrm{dS} / \mathrm{m}$ 'den yüksek olan topraklar tuzlu olarak sınıflandırılmaktadır [19]. İncelenen örneklerin elektriksel iletkenlik değeri bu değerden çok düşük olduğundan tuzluluk sorunu olmadığını göstermektedir (Tablo $1)$. 
Tablo 1. Toprakların bazı fizikokimyasal özellikleri

\begin{tabular}{|c|c|c|c|c|c|c|c|}
\hline \multirow{2}{*}{$\begin{array}{l}\text { Toprak } \\
\text { örneklerinin } \\
\text { alındığı yer }\end{array}$} & \multicolumn{3}{|c|}{ Toprak tekstürü (\%) } & \multirow{2}{*}{$\begin{array}{c}\text { Organilk } \\
\text { madde } \\
(\%)\end{array}$} & \multirow{2}{*}{$\begin{array}{c}\text { Kireç } \\
(\%)\end{array}$} & \multirow[t]{2}{*}{ pH } & \multirow{2}{*}{$\begin{array}{c}\text { EC } \\
(\mathbf{d S} / \mathbf{m})\end{array}$} \\
\hline & KUM & SILT & KİL & & & & \\
\hline Günören & 52.5 & 20.4 & 27.1 & 1.30 & 31 & 8.41 & 0.8 \\
\hline Uzunyol & 51.2 & 21 & 27.8 & 1.70 & 37 & 8.42 & 1.15 \\
\hline Akbilek & 62.3 & 19.1 & 18.6 & 1.50 & 31 & 8.34 & 0.72 \\
\hline Şükürali & 72.1 & 16.2 & 11.7 & 1.03 & 27 & 7.82 & 1.71 \\
\hline Ağcıl Köyü & 53.6 & 18.2 & 28.2 & 1.14 & 29 & 8.49 & 0.74 \\
\hline Balgat & 55.7 & 21.3 & 23 & 1.70 & 28 & 8.71 & 0.61 \\
\hline Aslanlı & 52.6 & 20.8 & 26.6 & 0.73 & 26 & 8.52 & 0.72 \\
\hline Seferköy & 53.4 & 21.7 & 24.9 & 1.51 & 33 & 8.57 & 0.76 \\
\hline Parapara & 48.4 & 23.8 & 27.8 & 1.19 & 31 & 8.51 & 0.64 \\
\hline İmambakır & 43.4 & 25.1 & 31.5 & 1.40 & 20 & 8.28 & 0.62 \\
\hline Uğurlu & 55.6 & 15.6 & 28.8 & 1.12 & 23 & 8.10 & 0.61 \\
\hline Topçu & 51.3 & 21.9 & 26.8 & 1.39 & 34 & 8.41 & 0.65 \\
\hline Ekinyazı & 47.2 & 24.6 & 28.2 & 1.73 & 35 & 8.24 & 1.28 \\
\hline Öncül & 61.7 & 18.5 & 19.8 & 1.81 & 26 & 8.49 & 0.61 \\
\hline Serince & 49.8 & 31.6 & 18.6 & 1.74 & 22 & 8.40 & 0.64 \\
\hline Ortaören & 50.7 & 18.2 & 31.1 & 1.59 & 31 & 8.12 & 0.51 \\
\hline Koruklu & 48.5 & 23.1 & 28.4 & 1.24 & 28 & 8.43 & 0.73 \\
\hline Karatepe & 52.6 & 19.8 & 27.6 & 1.52 & 22 & 8.51 & 0.67 \\
\hline Uğurhan & 54.2 & 19.1 & 26.7 & 1.56 & 24 & 8.47 & 0.59 \\
\hline Meydankapı & 53.5 & 21.6 & 24.9 & 1.91 & 31 & 8.39 & 0.80 \\
\hline Tatlica & 48.2 & 20.4 & 31.4 & 2.10 & 23 & 8.47 & 0.71 \\
\hline Öncüler & 54.9 & 19.8 & 25.3 & 0.80 & 35 & 7.92 & 0.75 \\
\hline Pekmezli & 47.6 & 24.3 & 28.1 & 1.90 & 27 & 8.52 & 0.57 \\
\hline Karatepe & 49.7 & 27.2 & 23.1 & 1.26 & 29 & 8.43 & 0.75 \\
\hline Keçili & 52.4 & 27.1 & 20.5 & 1.32 & 28 & 8.42 & 0.74 \\
\hline Acıkuyu & 44.2 & 28.5 & 27.3 & 1.97 & 31 & 8.40 & 0.64 \\
\hline Uğurtaș & 51.4 & 17.8 & 30.8 & 1.46 & 22 & 8.25 & 0.67 \\
\hline
\end{tabular}

Toprak kalitesinin biyolojik indikatörleri olarak ekstrasellüler enzimlerin kullanımı son yıllarda toprağın mikrobiyolojik yapısını tanımlamada sık kullanılan yöntemdir [11, 20-22]. Toprak örneklerinde belirlenen mikrobiyal biyomass karbon miktarı Tablo 2'de verilmiştir. Tablo 2'de görüldüğü gibi mikrobiyal biyomas karbon miktarı 98.2-198.5 mg C/100 g kuru toprak arasında değişmiştir. En yüksek mikrobiyal biyomass C miktarı Günören köyündeki mısır tarlası toprağından alınmıştır. Bu çalışmada incelenen verilere benzer olarak, yapılan çalışmalarda da mikrobiyal biyomas karbon üzerine organik maddenin etkili olduğu bildirilmiştir [24, 25]. Tarım arazilerinde mikrobiyal biyomas karbon miktarına, toprakta yetişen bitki çeşidi, uygulama yöntemleri, toprak nemi ve sıcaklığın etkili olduğu, ayrıca bitki köklerinden salgılanan rizosfer ürünleri ve kök artıkları ile toprağa giren karbon miktarının, mikrobiyal biyomas karbon içeriğini etkilediği rapor edilmiştir [25]. Mikrobiyal biyomas karbon içeriği ile dehidrogenaz, katalaz, toprakların silt, organik madde ve kireç içerikleri arasında korelasyon belirlenmiştir (Tablo 3). Toprakların mikrobiyal biyomas karbon ile katalaz aktiviteleri ve toprakların kireç içerikleri arasında 0.01 düzeyinde pozitif yönde ve anlamlı ilişki 
bulunmaktadır (Tablo 3). Toprakların mikrobiyal biyomas karbon içerikleri ile \%silt miktarı arasında negatif yönde 0.05 düzeyinde anlamlı ilişki, ayrıca toprak organik madde içeriği ile mikrobiyal biyomas karbon arasında pozitif yönde 0.01 düzeyinde anlamlı ilişki saptanmıştır. Toprakların enzim aktiviteleri ve mikrobiyal biyomas karbon içeriği üzerine toprakların fiziksel özelliklerinin etkileri farklı bulunmuştur. Toprakların fiziksel özelliklerinin, enzim aktiviteleri ve mikrobiyal biyomas karbon içeriği üzerine gösterdiği farklı etkiler, topraktaki organik madde düzeyinin düşük olmasından ve organik maddenin biyokimyasal yapısından ileri gelebilir.

$\beta$-glukosidaz, karbonhidratların degradasyonundan sorumlu olup, toprak heterotrofları için gelişme ve enerji kaynağı sağladığından toprak için önemli olarak düşünülmektedir $[21,23]$. $\beta$ glukosidaz aktivitenin toprakların işlenmesiyle de etkilendiği bildirilmiştir [16, 26]. Çalıştığımız toprak örnekleri arasında $\beta$-glukosidaz enzim aktivitesi 0.2-3.4 mg pnitrofenol/100g kuru toprak arasında değişiklik göstermiştir (Tablo 2). Yapılan çeşitli çalışmalarda da toprak özellikleri ve ürün tipine bağlı olarak $\beta$-glukosidaz aktivitenin değişiklik gösterdiği bildirilmiştir [8-9, 21]. Hoffmann ve Hofmann [17]; $\beta$-glukosidaz aktivitelerine göre toprakları; düşük $(<20)$, normal $(20-40)$ ve yüksek $(>20)$ olarak üç sınıfa ayırmışlardır. Araştırıcıların sınıflandırmasına göre, incelenen toprakların $\beta$-glukosidaz aktiviteleri düşük bulunmuştur (Tablo 2). $\beta$-glukosidaz aktivitenin düşük olması, toprakların organik madde içeriğinin düşük olmasından kaynaklanabilir. $\beta$-glukosidaz enzim aktivitenin özellikle toprak kalitesi için kullanılan enzim olduğu, toprak organik madde dönüşümünde esas rol oynadığ 1 bilinmektedir [16, 27].

Uygun substratın varlığında toprak mikroorganizmalarınca sentezlenen $\beta$-glukosidaz aktivitenin, topraklarda mikrobiyal biyomas karbon ve toplam karbon değerlerinde farklılıklara neden olduğu açıklanmıştır [16]. Yapılan bir çalışmada da, farklı bitki türlerinin yetiştiği topraklardan alınan örneklerde; dehidrogenaz, $\beta$-glukosidaz, üreaz ve fosfataz aktiviteleri incelenmiştir. Test edilen enzim aktivitelerinin bitki türlerine göre farklılık gösterdiği tespit edilmiştir [12]. Çalışmamızda da belirlendiği gibi, toprak örneklerinin dehidrogenaz aktivitesi 12.4-62.6 $\mu \mathrm{g}$ TPF / g kuru toprak arasında değişmiştir (Tablo 2). En yüksek aktivite Ekinyazı köyündeki mısır tarlasından alınan toprakta incelenmiştir. Dehidrogenaz üzerine toprağın kum içeriği negatif yönde önemli bulunmuştur (Tablo 3). Mısır yetiştirilen araştırma topraklarında üreaz aktivite değerlerinin 7.5-53.1 mg N/100g kuru toprak arasında değişiklik gösterdiği belirlenmiştir (Tablo 2). 
Tablo 2. Misır tarımı yapılan toprakların enzim aktiviteleri

\begin{tabular}{|c|c|c|c|c|c|c|}
\hline $\begin{array}{l}\text { Örneklerin } \\
\text { alındığı köyler }\end{array}$ & $\begin{array}{c}\text { Mikrobiyal } \\
\text { biyomas C } \\
\text { (mg C/100g } \\
\text { kuru toprak) }\end{array}$ & $\begin{array}{l}\text { Dehidrogenaz } \\
\text { ( } \mu \text { g TPF/g } \\
\text { kuru toprak) }\end{array}$ & $\begin{array}{l}\text { Katalaz (ml } \mathrm{O}_{2} \\
/ 5 \mathrm{~g} \text { kuru top.) }\end{array}$ & $\begin{array}{c}\beta \text {-glukosidaz } \\
\text { (mg p- } \\
\text { nitrofenol/ } 100 \\
\text { g toprak) }\end{array}$ & $\begin{array}{c}\text { Üreaz (mg } \\
\text { N/100g toprak) }\end{array}$ & $\begin{array}{c}\text { Alkalin } \\
\text { fosfataz } \\
\text { ( } \mu \mathrm{g} \mathrm{pNP} / \mathrm{g} \\
\text { kuru toprak) }\end{array}$ \\
\hline Günören & 198.5 & 60.7 & 10.6 & 1.64 & 32.1 & 37.1 \\
\hline Uzunyol & 169.2 & 32.1 & 5.2 & 0.82 & 31 & 43.4 \\
\hline Akbilek & 154.6 & 38.2 & 13.4 & 1.74 & 31.6 & 7.67 \\
\hline Şükürali & 162.4 & 24.6 & 9.2 & 0.96 & 43.2 & 7.04 \\
\hline Ağcıl & 137.6 & 29.9 & 4.6 & 0.2 & 26.3 & 48.5 \\
\hline Balgat & 158.2 & 43.1 & 1.5 & 0.2 & 13.7 & 77.1 \\
\hline Aslanlı & 121.4 & 39.6 & 2.9 & 3.4 & 44.8 & 20.47 \\
\hline Seferköy & 158.2 & 26.3 & 4.4 & 0.6 & 53.1 & 70.4 \\
\hline Parapara & 174.3 & 62.4 & 8.9 & 0.7 & 14.6 & 61.7 \\
\hline İmambakır & 120.1 & 41.3 & 5.8 & 0.52 & 12.7 & 61.2 \\
\hline Uğurlu & 128.2 & 52.6 & 2.6 & 0.46 & 11.3 & 63.2 \\
\hline Topçu & 167.3 & 55.4 & 11.8 & 1.3 & 34 & 28.2 \\
\hline Ekinyazı & 102.4 & 62.6 & 2.1 & 1.2 & 28 & 57.4 \\
\hline Öncül & 98.2 & 30.4 & 1.3 & 1.71 & 21 & 68.7 \\
\hline Serince & 112.4 & 41.2 & 1.9 & 0.5 & 16 & 80.2 \\
\hline Ortaören & 138.2 & 52.9 & 4.6 & 1.6 & 21 & 82.4 \\
\hline Koruklu & 130.1 & 51 & 2.9 & 2 & 23.5 & 59.2 \\
\hline Karatepe & 110.4 & 30.7 & 9.1 & 1.4 & 9.2 & 48 \\
\hline Uğurhan & 176.9 & 53.3 & 1.8 & 1.6 & 21 & 53.1 \\
\hline Meydankapı & 114.2 & 36.8 & 0.4 & 1.3 & 42 & 48.5 \\
\hline Tatlıca & 110.4 & 12.4 & 1.5 & 0.5 & 31.2 & 29.7 \\
\hline Öncüler & 142.6 & 45.4 & 0.51 & 0.6 & 8.5 & 61.9 \\
\hline Pekmezli & 132.4 & 43.7 & 2.3 & 1.2 & 26 & 45.6 \\
\hline Karatepe & 128.6 & 40.2 & 1.6 & 2.3 & 36.9 & 47.8 \\
\hline Keçili & 126.5 & 51.2 & 5.1 & 0.7 & 27.4 & 39.7 \\
\hline Acıkuyu & 112.9 & 48 & 4.06 & 1.8 & 7.5 & 69.9 \\
\hline Ŭ̆urtaş & 148.5 & 38 & 5.5 & 0.8 & 28 & 25.7 \\
\hline
\end{tabular}

Karaca ve ark. [8] fındık tarımı yapılan toprakların üreaz aktivitesinin 6.5-35 mg N/100g toprak arasında değiştiğini, buna karşın Bafra ovasında çeltik tarımı yapılan topraklarda üreaz aktivitenin ise 24.12-39.03 mg N/100g kuru toprak arasında değiştiği Kızılkaya ve ark. [9] tarafindan bildirilmiştir. Hoffmann ve Hofmann [17] toprak örneklerindeki üreaz aktivite değeri 8'den küçük olduğunda düşük, 8-16 arasında ise normal, 16'den fazla ise yüksek seviye olduğunu belirtmişlerdir. Hoffmann ve Hofmann [17] üreaz enziminin toprak kolloidlerince sıkıca tutulduğunu belirtmişlerdir. Üreaz aktivitenin baklagil ekilen topraklarda daha fazla bulunduğunu ve bu durumun baklagil köklerindeki nodül bakterilerinden kaynaklanabileceği ifade edilmiştir [28]. Üreaz aktivitenin organik karbon, toplam azot, katyon değişim kapasitesi, kum yüzdesi gibi farklı toprak özellikleri ile korelasyon gösterdiği rapor edilmiştir [28]. Frankenberger ve Dick [28] tarafından yapılan çalışmada, üreaz ile toprak özellikleri, mikrobiyal biyomas, solunum ve mikroorganizma popülasyonu arasında önemli bir ilişkinin olmadığı belirlenmiştir. Çalışmamızda da, mısır yetiştirilen topraklardan alınan örneklerde üreaz aktivitenin toprakların kum içerikleri ile pozitif yönde korelasyon göstermesi 
Frankenberger ve Dick [28]'in bulgularıyla benzerlik göstermektedir. Frankenberger ve Dick [28], toprak üreaz aktivitesinin toprakta yetiştirilen ürün tipi ile ilişkili olduğunu, üreaz aktivitenin baklagil ekili tarla topraklarında baklagil yetiştirilmeyen topraklardakinden daha yüksek olduğunu açıklamışlardır. Her kültür toprağının bulunduğu çevre koşullarına göre bir enzim seviyesi olduğu, bu enzim seviyesinin topraklara eklenen organik ve inorganik gübrelerin çeşit ve miktarına, hasat sonrası toprağa karışan hasat artıklarının içeriklerine göre değişiklik gösterdiği yapılan çalışmalarda bildirilmiştir [5, 21, 25].

Tablo 3. İncelenen toprak özellikleri arasındaki korelasyon katsayıları

\begin{tabular}{|c|c|c|c|c|c|c|c|c|c|c|c|c|}
\hline & $\mathbf{A}$ & B & C & D & $\mathbf{E}$ & F & G & $\mathbf{H}$ & I & $\mathbf{J}$ & $\mathbf{K}$ & $\mathbf{L}$ \\
\hline $\mathbf{A}$ & 1 & & & & & & & & & & & \\
\hline B & 0.27 & 1 & & & & & & & & & & \\
\hline C & $0.52^{* * *}$ & 0.14 & 1 & & & & & & & & & \\
\hline D & -0.12 & 0.18 & 0.069 & 1 & & & & & & & & \\
\hline $\mathbf{E}$ & 0.187 & $-0.32^{*}$ & 0.125 & 0.219 & 1 & & & & & & & \\
\hline $\mathrm{F}$ & -0.24 & 0.25 & $-0.503^{* *}$ & -0.237 & $-0.54^{* * * *}$ & 1 & & & & & & \\
\hline $\mathbf{G}$ & 0.25 & $-0.31^{*}$ & 0.221 & -0.009 & $0.278^{*}$ & $-0.43^{* *}$ & 1 & & & & & \\
\hline $\mathrm{H}$ & $-0.32^{*}$ & 0.23 & -0.175 & 0.109 & -0.125 & $0.323^{*}$ & $-0.58^{* * *}$ & 1 & & & & \\
\hline I & -0.11 & 0.14 & -0.192 & -0.028 & -0.249 & $0.343^{*}$ & $-0.72^{* * *}$ & 0.059 & 1 & & & \\
\hline $\mathrm{J}$ & $-0.31^{*}$ & -0.21 & -0.245 & -0.190 & -0.091 & 0.251 & $-0.28^{*}$ & $0.289^{*}$ & 0.13 & 1 & & \\
\hline $\mathbf{K}$ & $0.36^{* *}$ & 0.23 & 0.191 & 0.057 & 0.268 & 0.025 & 0.013 & 0.037 & 0.12 & -0.05 & 1 & \\
\hline $\mathbf{L}$ & -0.04 & -0.06 & -0.100 & 0.134 & 0.068 & 0.212 & $-0.41^{* *}$ & $0.304^{*}$ & $0.219^{* *}$ & -0.38 & -0.037 & 1 \\
\hline
\end{tabular}

A:Mikrobiyal Biyomas C, B: Dehidrogenaz, C:Katalaz, D: $\beta$-glukosidaz, E:Üreaz, F:Alkalin fosfataz, G:Kum, H: Silt, I:Kil, J:Organik madde, K:Kireç, L:pH $\quad *$ : \%5 düzeyinde, **: \%1 düzeyinde, ***\%0,1 düzeyinde önemli

Smith ve Read [29] tarafından yapılan çalışmada; Çek cumhuriyetinin farklı bölgelerinden alınan toprak örneklerinde fosfataz enzim aktivitesini saptamışlar ve fosfataz aktivite ile toprakların $\mathrm{pH}$, organik karbon ve toplam fosfor içerikleri arasında korelasyon olduğunu açıklamışlardır. Şanlıurfa'da mısır tarımı yapılan topraklardan alınan örneklerde alkali fosfataz aktivitenin 7.04-82.4 $\mu \mathrm{g}$ PNP/g kuru toprak arasında değiştiği belirlenmiştir (Tablo 2). Toprakların organik madde içerikleri ve parçalanma oranları, dolayısıyla toprağın mikrobiyal yoğunluğu biyolojik aktiviteyi etkilemektedir. Çalıştığımız bölge toprakları sürekli işlenmektedir ve çalışma alanlarında mısır tarımının yapıldığı tarihlerde sıcaklık oldukça yüksek olmaktadır. Buna bağlı olarak bu sürede, toprağın nem içeriği de düşüktür. Çalışma alanında yağış az, buharlaşma oldukça yüksektir. Dolayısıyla, topraklara karışan organik atıkların parçalanmasını sağlayan etkin mikroorganizma sayısının yetersiz olabileceği düşünülmektedir. Etkin mikroorganizma sayısının az olması, organik madde parçalanmasını da olumsuz etkilediğinden, çalışılan toprakların aktivite değerleri oldukça düşük bulunmuştur. Yapılan çeşitli çalışmalarda da, toprakların biyolojik aktiviteleri üzerine toprak özelliklerinin farklı bulunmasının nedeninin, çalışma alanlarının iklim şartlarının farklı olmasından ve 
topraklarda yetiştirilen ürün çeşidinin farklılığından kaynaklanabileceği düşünülmektedir [8, 28].

Alkalin fosfataz enzim aktivitesi üzerine toprak özelliklerinin etkisini belirlemek için yapılan korelasyon Tablo 3'de verilmiştir. Tablo 3'e göre; mısır tarlası topraklarının alkalin fosfataz enzim aktivitesi üzerine katalaz, üreaz, toprağın kum içeriği negatif yönde etki ederken, toprağın kil ve silt içeriği ise pozitif yönde etki etmiştir (Tablo 3). Fosfatazın agronomik öneminin olduğu, organik fosforu hidrolize ederek bitkiler için gerekli inorganik fosforun farklı formlarına dönüştürdüğü bildirilmiştir [30]. Topraktaki enzim aktivitelerinin aktif toprak biyoması ile ilişkili olduğu ve toprak enzim aktiviteleri toprak kalitesinin duyarlı indikatörleri olarak tanımlanmıştır [21]. Topraklarda alkalin fosfataz, amidaz ve katalaz aktivitenin mikrobiyal popülasyonun aktivitesiyle de ilişkili olduğu düşünülmüştür [28].

Katalaz, canlılar için zehirli olan hidrojen peroksiti su ve hidrojene parçalayan enzimdir [7]. Katalazın substratı olan hidrojen peroksitin mikroorganizmalar için toksik olduğu açıklanmıştır [28]. Tüm aerobik ve aerotolerant bakterilerin $\mathrm{H}_{2} \mathrm{O}_{2}$ 'i oksijen ve suya parçaladığı bilinmektedir. Hidrojen peroksitin parçalanma oranı yani katalaz aktivitenin varlığının, aerobik mikrobiyal popülasyonun aktivitesi ve biyokütlesiyle ilişkili olduğu bildirilmiştir [7, 28]

Alef ve Nannipieri [30] tarafından yapılan bir araştırmada; katalaz aktivitesinin toprakta çok stabil olduğunu rapor etmişlerdir. Araştırıcılar, katalazın toprak derinliği ile azaldığını ve organik karbon içeriği ile önemli korelasyon gösterdiğini bildirmişlerdir. Çalışmamızda ise, katalaz üzerine mikrobiyal biyomas karbon pozitif yönde önemli bulunmuştur. Bu da, Alef ve Nannipieri [30]'in yapmış oldukları çalışmanın bulguları ile uyumludur. Yapılan çalışmalarda toprakların katalaz aktivitesi örneklerin alındığı bölge topraklarına göre değişiklik göstermiştir [9, 10]. Toprak katalaz aktivitesinin toprağın verimlilik düzeyi, karbon içeriği, azot içeriği, toprak partiküllerinin büyüklüğü ile ilişkili olduğu açıklanmıştır [27].

Wang ve ark. [31], Yuan ve ark. [32] ekili topraklarda katalaz aktivitesinin bakteriyal ve fungal mikroorganizma populasyonu, toprağın değişebilir katyon kapasitesi ile ilişkili olduğunu tespit etmişlerdir. Çalışmamızda en yüksek katalaz aktivite Akbilek köyünden alınan mısır tarlası toprağında $13.4 \mathrm{ml} \mathrm{O}_{2} / 5 \mathrm{~g}$ kuru toprak olarak belirlenmiştir. Toprağa uygulanan gübre miktarı ve ürün rotasyonunun toprak katalaz aktivitesini etkilediği Mijangos ve ark. [5] tarafindan bildirilmiştir. Katalaz aktivitenin; kil içeriği, toprak nemi, toprak derinliği, sıcaklık, organik madde miktarı, $\mathrm{pH}$, toprak tipine göre farklılık gösterdiği ve aktivitenin toprak işlemesiyle artış gösterdiği tespit edilmiştir [11]. İncelenen topraklarda da katalaz aktivitenin düşüklüğü toprağın 
kil içeriğinden kaynaklanabileceği gibi, besin maddesince fakir olmasından ve dolayısıyla ortamda mevcut mikroorganizma popülasyonundan ve sicaklığın yüksek olmasından kaynaklanabilir. Kil bünyeye sahip topraklar gübreleme gibi herhangi bir kültürel işlemin yapılmadığı durumlarda, daha fazla alınabilir besin maddesi konsantrasyonu içermektedir. Oysa çalışma alanındaki topraklar kil bünyeye sahip fakat sürekli olarak işlenmektedir. Shahbazi ve ark. [22] proteaz, üreaz, dehidrogenaz enzim aktivitelerinin toprak tipine göre farklılık gösterdiğini ve toprak işlemesiyle artış gösterdiğini bildirmişlerdir. Enzim aktivitelerinin düşüklüğünün; toprakların kil kapsamları, kilden kaynaklanan adsorpsiyon kapasiteleri, havalanma ve mikroorganizma populasyonuna bağlı olduğu açıklanmıştır [26].

\section{SONUÇLAR}

Sonuç olarak, bu çalışmada; toprak enzim aktivitelerinin düşüklüğünün, toprağın organik maddesinin düşük olmasının yanı sıra, toprakların sürekli olarak işlenmesi, çiftçilerin uyguladıkları gübreleme, tarımsal ilaçlar gibi kültürel yöntemlerden de kaynaklanabileceği düşünülmektedir. Toprak örnekleri bitkinin hasat zamanına yakın alındığından toprağa herhangi bir girdinin olmaması mikrobiyal aktiviteyi uyarmadığı ve dolayısıyla, toprakların enzimatik aktivitelerinin düşük olmasına da neden olabilir. Çalışma alanımızdan alınan toprakların organik madde içerikleri düşük olduğundan test edilen mikrobiyolojik aktivite değerleri de düşük bulunmuştur. Topraklara uygulanacak organik materyaller toprağın fiziksel ve kimyasal özelliklerini iyileştirmesinin yanı sıra toprakların mikrobiyal aktivitesini de arttıracağından tarımsal üretimde yüksek verim alınmasını sağlayacaklardır.

\section{KAYNAKLAR}

[1] Y. Kırtok, Misır üretimi ve kullanımı. Kocaoluk Yayıncılık, (1998) pp. 446.

[2] Anonim, 2017. www.zmo.org.tr

[3] A. Öktem, A. Öktem, Y. Coşkun, Determination of sowing dates of sweet corn (Zea mays L. Saccharata Sturt.) under Şanliurfa conditions. Turkish Journal of Agriculture and Forestry. 28 (2004) 83-91.

[4] R.P. Dick, Soil enzyme activities as integrative indicators of soil health. In: Pankhurst, C.E., Douhe, B.M., Gupta, V.V.S.R. (eds). Biological indicators of soil health. CAB Intern. Wallingford, UK, (1997) pp.121-156.

[5] I. Mijangos, R. Perez, I. Albizu, C. Garbisu, C, Effects of fertilization and tillage on soil biological parameters. Enzym. Microbiol. Technol. 40 (2006) 100-106.

[6] F. Gill-Sotres, C. Trasar-Cepeda, M. C. Leiros, S. Seoane, S. Different approaches to evaluate soil quality using biochemical properties. Soil Biol. Biochem. 37 (2005) 877-887.

[7] J. Liu, J. Xie, Y. Chu, C. Sun, C. Chen, Q. Wang, Combined effect of cypermethrin and copper on catalase activity in soil. J. Soils Sediments. 8 (2008) 327-332. 
[8] A. Karaca, R. Kızılkaya, A. Horuz, S. Arcak, Findık tarımı yapılan toprakların biyokimyasal aktivite özellikleri ile toprak özellikleri arasındaki ilişkiler. Pamukkale Üniv. Müh. Bilimleri Dergisi. 4 (1998) 813-822.

[9] R. Kızılkaya, S. Arcak, A. Horuz, A. Karaca, Çeltik tarımı yapılan toprakların enzim aktiviteleri üzerine toprak özelliklerinin etkisi. Pamukkale Üniversitesi Mühendislik Bilimleri Dergisi, 4 (1998) 797-804.

[10]I. Onaç, M. Gök, Gaziantep-Kayacık ve Gaziantep-Kemlin ovalarında yer alan yaygın toprak serilerinin bazı mikrobiyolojik özelliklerinde inkübasyon süresine bağll olarak meydana gelen değişmeler. Tr. J. Agri. Forestry. 18 (1994) 337-344.

[11]C. Tresar-Cepeda, M. C. Leiros, S. Seoane, C. Gill-Sotres, Biochemical properties of soils under crop rotation. Applied Soil Ecology. 39 (2008) 133-143.

[12]C. Garcia, A. Roldan, T. Hernandez, Ability of different plant species to promote microbiological processes in semiarid soil. Geoderma. 124 (2005) 193-202.

[13] B. Kacar, Toprak analizleri. Nobel Basımevi, Ankara. Yayın no:44 (2009) sayfa 467

[14] J.P.E. Anderson, K.H. Domsch, A physiological method for the quantitative measurement of microbial biomass in soils. Soil Biol. Biochem. 10 (1978) 215-221.

[15] I.L. Pepper, C.P. Gerba, J.W. Brendecke, Brendecke:Environmental Microbiology, A Laboratory Manual. Academic Press, New York (1995)

[16] B.L. Turner, D.W. Hopkins, P.M. Haygarth, N. Ostle, $\beta$-glucosidase activity in pasture soils. Applied Soil Ecology. 20 (2002) 157-162.

[17]E. D. Hofmann, G.G. Hoffmann, Die Bestimmug Der Biologischen Tatigheit in Böden Mit Enzymethoden. Reprinted From Advances in Enzymology and Related Subject of Biochemistry, 28 (1966) 365-390

[18] M.A. Tabatabai, J.M. Bremner, Use of p-nitrophenyl phosphate for assay of soil phosphatase activity. Soil Biology and Biochemistry. 1 (1969) 301-307.

[19] M.E. Sumner, Sodic soils: new perspectives. R. Naidu, M.E. Sumner, P. Rengasamy (Eds.), Australian Sodic Soils: Distribution, Properties and Management, CSIRO, Melbourne (1995) pp. 1-34

[20] M. Maharjan, M. Sanaullah, B.M. Razavi, Y. Kuzyakov, Effect of land use and management practices on microbial biomass and enzyme activities in subtropical top-and sub-soils. Applied Soil Ecology. 113 (2017) 22-28.

[21] S. Jian, J. Li, J. Chen, G. Wang, M.A. Mayes, K.E. Dzantor, D. Hui, Y. Luo, Soil extracellular enzyme activities, soil carbon and nitrogen storage under nitrogen fertilization: A meta-analysis. Soil Biology and Biochemistry, 101 (2016) 32-43

[22]F. Shahbazi, N. Aliasgharzah, S.A. Ebrahimzad, N. Najafi, Geostatistical analysis for predicting soil biological maps under different scenarios of land use. European Journal of Soil Biology. 55 (2013) 2027.

[23] M.A. Kader, S.Yeasmin, Z.M. Solaiman, S. De Neve, S. Sleutel, Response of hydrolytic enzyme activities and nitrogen mineralization to fertilizer and organic matter application in subtropical paddy soils. European Journal of Soil Biology. 80 (2017) 27-34.

[24] Y. Zhang, P. Marschner, Residue addition combined with rewetting of dry soil - Effect of timing of residue addition on soil respiration, microbial biomass, nutrient availability and legacy effect. Geoderma, 299 (2017) 83-90.

[25] J.P. van Leeuwen, I. Djukic, J. Bloem, T. Lehtinen, T. Hemerik, L.P.C. de Ruiter, G.J. Lair, Effects of land use on soil microbial biomass, activity and community structure at different soil depths in the Danube floodplain. European Journal of Soil Biology. 79 (2017) 14-20

[26] C.M. Monreal, D.W. Bergstrom, Soil enzymatic factors expressing the influence of land use, tillage system and texture on soil biochemical quality. Can. J. Soil Sci. 80 (2000) 419-428. 
[27] V. Kabiri, F. Raiesi, M.A. Ghazavi, Tillage effects on soil microbial biomass, SOM mineralization and enzyme activity in a semi-arid Calcixerepts. Agriculture, Ecosystems \& Environment. 232 (2016) 7384.

[28] W.T. Frankenberger, W.A. Dick, Relationships between enzyme activities and microbial growth and activity indices in soil. Soil Sci. Soc. Am. J. 47 (1983) 945-951.

[29] S.E. Smith, D.J. Read, Mycorrhizal symbiosis. Academic Press, London, (1997).

[30] A. Alef, P. Nannipieri, Catalase activity. In: Alef, K., Nannipieri, P. (Eds.), Methods in Applied Soil Microbiology and Biochemistry. Academic Press, London, U.K., (1995) pp, 2362-363.

[31] Y. Wang, F. Fu, J. Li, G. Wang, M. Wu, J. Zhan, X. Chen, Z. Mao, Effects of seaweed fertilizer on the growth of Malus hupehensis Rehd. seedlings, soil enzyme activities and fungal communities under replant condition. European Journal of Soil Biology, 75 (2016) 1-7.

[32]Z.M. Yuan, H.J. Liu, J. Han, J.J. Sun, X.Y. Wu, J. Yao, Monitoring soil microbial activities in different cropping systems using combined methods. Pedosphere. 27 (2017) 138-146. 